\title{
NON-THERMAL BIOMARKERS OF EXPOSURE TO RADIOFREQUENCY/MICROWAVE RADIATION
}

\author{
Ivančica TROŠIĆ, Ivan PAVIČIĆ, Ana Marija MARJANOVIĆ, and Ivana BUŠLJETA \\ Institute for Medical Research and Occupational Health, Zagreb, Croatia
}

Received in June 2011

CrossChecked in April 2012

Accepted in April 2012

\begin{abstract}
This article gives a review or several hypotheses on the biological effects of non-thermal radiofrequency/ microwave (RF/MW) radiation and discusses our own findings from animal and in vitro studies performed over the last decade. We have found that RF/MW radiation disturbs cell proliferation and leads to cell differentiation in the bone marrow, which is reflected in the peripheral blood of rats. Repeated RF/MW radiation can also temporarily disrupt melatonin turnover. The observed changes seem to be a sign of adaptation to stress caused by irradiation rather than of malfunction. The article looks further into the basic mechanisms of RF/MW biological action, including cell growth parameters, colony-forming ability, viability, and the polar and apolar protein cytoskeleton structures. The observed reversible cell changes significantly obstructed cell growth. In contrast to the apolar intermediate proteins, the intracellular polar microtubule and actin fibres were damaged by radiation in a time-dependent manner. These significantly altered parameters can be considered as the biomarkers of exposure. Future research should combine dosimetry, experimental studies, and epidemiological data.
\end{abstract}

KEY WORDS: $R F / M W$, non-thermal, radiation, biological markers, in vivo, in vitro

The opinion of the Scientific Committee on Emerging and Newly Identified Health Risks (EUSCENIHR) of Exposure to EMF (electromagnetic fields) of 19 January 2009 could be summarised as follows; three independent lines of evidence (epidemiological, animal, and in vitro studies) suggest that exposure to RF fields at non-thermal exposure level is unlikely to lead to an increase in cancer incidence, to genotoxic effects and DNA damage in humans and animals, or to influence reproductive system, cognitive and sensory functions, structural sensitivity and cellular response. "However," the Committee says, "as the widespread duration of exposure of humans to RF fields from mobile phones is shorter than the induction time of some cancers, further studies are required to identify whether considerably longer-term (well beyond ten years) human exposure to such phones might pose some cancer risk". Furthermore, the Committee has acknowledged that the report does not include the effects caused by RF fields in children and strongly suggested further investigation of the health relevance and mechanisms of RF biological action (1).

This article reviews several hypotheses on the biological action of non-thermal RF/MW radiation and discusses the results of our own animal and in vitro studies performed over the last decade.

\section{HYPOTHESES ON NON-THERMAL RF/MW RADIATION BIOLOGICAL EFFECTS}

Current RF safety standards are intended to prevent thermal action of RF/EMF radiation on the living tissue. This, however, does not exclude non-thermal 
biological effects $(2,3)$. Non-thermal effects occur when the emitted energy of the RF field does not significantly increase the temperature of a cell, tissue, or an organism, but does bring to some physical or biochemical changes (4). A half-hour exposure to high-frequency, low-intensity EM fields within the SAR range of $1 \mathrm{~W} \mathrm{~kg}^{-1}$ to $4 \mathrm{~W} \mathrm{~kg}^{-1}$ body weight can raise temperature up to the $1{ }^{\circ} \mathrm{C}$ in adult healthy people. This rise does not disturb the thermal equilibrium and is regarded as physiologically acceptable (5).

There are several hypotheses on how non-ionising radiation, which includes RF, visible light, infrared and other electromagnetic (EM) forms of radiation, can affect organisms at a non-thermal level. One is that $\mathrm{RF}$ radiation can change cell membrane signal transduction. This change can decrease ion channel formation and the frequency of single-channel openings. It can also affect membrane transport of cations such as $\mathrm{Na}^{+}, \mathrm{K}^{+}$and $\mathrm{Ca}^{2+}$, binding to the membrane surfaces (6).

Another effect of non-thermal RF radiation on the membrane structure may be the formation of free radicals. Non-ionising radiation might induce oxidative stress by generating reactive oxygen species, that can accumulate to the point when they can lead to a number of diseases $(7,8)$.

The third, Fröhlich's hypothesis gives a reasonable explanation why biological markers appear at nonthermal levels of 'RF radiation. Fröhlich argues that large molecules in the biological tissue could vibrate at frequencies that allow for absorption of external energy. He also wonders whether a living organism might behave in a manner similar to a radio receiver and amplify a weak signal when it tunes to the frequency of the carrier wave. It creates a resonant circuit that responds only to a narrow radiofrequency bandwidth $(9,11)$. In other words, electromagnetic radiation in the microwave range could create a resonance in the molecules of living organisms. This resonance is one possible non-thermal biological effect. It occurs when the wave-length of EM radiation is in the range of the properties of biological tissue.

Cell membrane receptors seem to be the first site of interactions between $\mathrm{RF} / \mathrm{MW}$ radiation and many neurotransmitters, hormones, growth-regulating enzymes, and cancer-promoting agents (10). Furthermore, RF irradiation seems to induce electric oscillations that disturb cell membrane proteins (11) and activate enzyme cascades that may transfer cell surface signals to the intracellular system, including cell nuclei and cell growth and division (12).
Animal studies play a critical role in evaluating the reactions of various body systems to irradiation. However, phenomena seen in animals do not necessarily imply a health risk for people. Furthermore, biomarkers of non-thermal radiation are not necessarily associated with adverse health effects, at least not in short-term exposure.

\section{RF/MW INFLUENCE ON THE HAEMATOPOIESIS IN RATS}

Our investigation started with testing the biological potency of the RF/MW field on whole-body irradiated rats (13). As haematopoietic cells are more sensitive to radiation than cells in many other tissues (14), we were encouraged to investigate $\mathrm{RF} / \mathrm{MW}$ radiation effects on bone marrow cells in a sub-chronic, thirtyday exposure. We found a decrease in anuclear cells and erythropoietic precursor cells, increase in micronucleated cells in the bone marrow, and increase in erythrocyte count, blood haemoglobin, and blood haematocrit. Polychromatic erythrocyte (PCE) count showed no significant differences between RF/MWexposed and control animals on the final day of our experiment. After a sharp rise at the beginning of exposure, PCE counts normalised by the end of the experiment thanks to an adaptive mechanism involved in cell proliferation and maturation $(15,16)$. These results are consistent with our findings of a transitory influx of immature erythrocytes into the peripheral circulation in rats exposed to sub-chronic $2.45 \mathrm{GHz}$ irradiation (17). This consequence of applied radiation on erythropoieic cells is reversible, as the homeostatic control mechanism kicks in (18). Transitory aberrations in cell proliferation may result in a significant but also transitory increase in micronucleus (MN) formation in the bone marrow erythropoietic cells. Micronucleated PCEs observed in animal blood after having received 15 irradiation treatments of two hours each appear to be due to the elimination of severely damaged, micronucleated cells by the mononuclear-phagocyte system(MPS) that consists of macrophages, monocytes, promonocytes, and their precursor cells in the bone marrow. In addition to phagocytosis, these cells also synthesise several cytokines that participate in haematopoiesis (19). These cytokines could be involved in a mechanism through which low-level $\mathrm{RF} / \mathrm{MW}$ radiation affects erythrocytopoiesis. Some studies have confirmed altered phagocytic and 
secretory function of peritoneal and alveolar macrophages after MW radiation $(20,21)$.

In another study, we also observed a slight drop in nucleated cell count at the beginning of irradiation and a significant decrease in lymphoblast count at the end, but they did not affect the total lymphocyte count in the bone marrow over the 30-day experiment. Blood leukocyte and lymphocyte counts remained within the normal range observed in control animals (22). This response to radiation-induced stress in the bloodforming system provoked by the irradiation suggests that the changes are rather a sign of adaptation than of malfunction (23).

\section{MELATONIN HYPOTHESIS}

The melatonin hypothesis proposed by Stevens and Davis in 1996 (24) has stood out due to a report that EMF lowered nocturnal melatonin concentrations (25) and hence its oncostatic potential (i.e., its capability to inhibit cancer cell growth and/or affect the immune system). Three mechanisms have been proposed that explain how EMFs can increase cancer risk by lowering melatonin concentrations: 1) lower melatonin concentrations could lead to higher oestrogen and prolactin concentrations and eventually to higher incidence and prevalence of hormonally mediated cancers; 2) considering melatonin's anti-oxidative properties, lowering its levels could increase DNA susceptibility to damage and eventually the overall cancer risk; and 3) considering melatonin's ability to inhibit cell proliferation, lower concentrations could be relevant for cancer development in general (24).

Several studies have shown that EM radiation across almost the entire non-ionising electromagnetic spectrum (extremely low frequencies to RF/MW) lowers melatonin levels both in animals and humans. In our study, we followed the levels of rat nocturnal urinary aMT6s during RF/MW exposure. As repeated exposure failed to produce irreparable damage, we concluded that this biological stressor puts melatonin turnover out of balance only transiently, probably due to an effective adaptive response in rats (26).

\section{CELLULAR BIOMARKERS OF RF/MW EXPOSURE}

In vitro experiments could help to understand the basic mechanisms of $\mathrm{RF} / \mathrm{MW}$ action that are responsible for more complex effects in animals or humans (such as adverse cell transformation, tumour formation, changes in brain activity or even behaviour). Therefore, we evaluated and compared the effects of $864 \mathrm{MHz}$ and $935 \mathrm{MHz}$ microwave fields on the basic growth parameters of cultured cells: growth, colonyforming ability, and cell viability. Cell growth slowed down after one two- and three-hour exposure to the $864 \mathrm{MHz}$ field (SAR $0.08 \mathrm{~W} \mathrm{~kg}^{-1}$ ). Cells exposed to the $935 \mathrm{MHz}$ field (SAR $0.12 \mathrm{~W} \mathrm{~kg}^{-1}$ ) for three hours also showed a significantly lower growth 72 hours after exposure in comparison to control. Colonyforming ability and cell viability did not significantly differ between the exposed and control cells $(27,28)$. These results are in accordance with the explanation given by Kwee and Rasmark (29), who found growth suppression of human epithelial amnion cells exposed to $960 \mathrm{MHz}$ radiation within the SAR range between $0.021 \mathrm{~W} \mathrm{~kg}^{-1}$ and $2.1 \mathrm{~W} \mathrm{~kg}^{-1}$. The authors pointed to a so-called "window" effect, that is, the maximum effect on cell proliferation rate was related to a specific electromagnetic field and to exposure time. These effects are not linear over the whole radiofrequency spectrum. Grundler et al. $(30,31)$ observed that some frequencies increased the growth rate of the yeast Sacharomyces cerevisiae up to $15 \%$ or and other lowered it by $29 \%$. The resonance bandwidths were of the order of $10 \mathrm{MHz}$. This confirmed the theoretical assumption of coherent molecular oscillations that could activate cellular metabolic processes.

An external electric field in the frequency range similar to the physiological ones can dissipate essential cellular proteins in the cytoskeleton. Cytoskeleton structures with electric dipole moments can generate oscillating electric fields, and an external electromagnetic field can contribute to their excitation (32). Inasmuch as the fundamental structure such as microtubule proteins is disturbed by irradiation, it is reasonable to assume that this could affect cell growth. We tested this assumption by exposing a continuous V79 cell line to an $864 \mathrm{MHz}$ continuous wave at an average SAR of $0.08 \mathrm{~W} \mathrm{~kg}^{-1}$ under strictly controlled experimental conditions. Irradiation significantly affected cell proliferation but not viability or colonyforming ability (33).

In vitro approach gives a more accurate insight into this mechanism, particularly when it comes to the polar protein structures. Microtubule fibres are a dynamic structure whose functioning depends on continuous binding and releasing of free tubule proteins. Depending on the dipole moment, an external 
electric field could, in theory, disturb the equilibrium and increase the number of free cytoplasmatic tubule proteins (34).

The Fröhlich model has encouraged further research. Pokorný et al. (35-37) have suggested that macromolecular polymers and proteins contained in microtubules vibrate in the same range as radiofrequency. Their dipole molecular assembly might be highly vulnerable to electromagnetic radiation. Our study on the effects of RF field on the polymerisation and depolymerisation of cytoskeleton fibres has shown that external RF fields can interact with these polar structures and contribute to their excitation (38). We confirmed increased and timedependent impairment of the microtubule structure after UHF radiation (39). Low-intensity $935 \mathrm{MHz}$ radiation can affect microtubule proteins and suppress cell growth. Pacini et al. (40) studied the effects of modulated UHF radiation $(902.4 \mathrm{MHz}$, SAR $0.6 \mathrm{~W} \mathrm{~kg}$ 1) on fibroblast cells after one hour of exposure. They reported morphological changes caused by increased expression of genes coded for structural proteins. In contrast, Stagg's group (41) did not observe any changes in cell transition through the G1, G2, and S phase and in cell division immediately after exposure to modulated $835.62 \mathrm{MHz}$ wave (SAR $0.6 \mathrm{~W} \mathrm{~kg}^{-1}$ ) for up to $100 \mathrm{~h}$. However, two independent groups of investigators demonstrated the capability of lowpower UHF radiation to induce reversible changes to cell protein structure, affect beta-lactoglobulin conformational changes, and stimulate the unfolding of citrate synthase (42-44). In addition, Leszczynski et al. (45) found that mobile phone radiation changes the phosphorylation status of the heat shock protein27 , one of the stress family proteins. These findings have been corroborated by Marjanović et al. (46) who found that the RF field of $1.5 \mathrm{GHz}$ to $10.9 \mathrm{GHz}$ impaired antioxidative defence on the macromolecular level in humans.

\section{RESEARCH NEEDS FOR LABORATORY STUDIES}

The 2010 World Health Organization (WHO) Research Agenda for Radiofrequency Fields (47) speaks about the need for further epidemiological, laboratory, and dosimetry investigation to identify possible adverse health effects and to provide information on appropriate levels of protection. As Rapacholi (48) puts it: "While in vitro studies can provide important insights into fundamental mechanisms for biological effects from exposure to low-level EMF, in vivo studies, whether on animals or human beings, provide more convincing evidence of adverse health consequences. Epidemiological studies provide the most direct information on risks of adverse effects in human beings. However, these studies have limitations, especially when low relative risks are found".

\section{Laboratory studies: Animals}

Animal studies should include animals with clear responses to RF exposure, and RF frequency signals should be relevant for human use (commercial frequencies). They should compare responses to RF fields between young and adult animals and investigate the dose-response relationship (47).

\section{Laboratory studies: Tissues, cells, and cell-free systems}

Studies in tissues, cells, and cell-free systems play a supporting role in public health risk assessments and are critical to the optimal design of animal and epidemiology studies. They should use cellular systems with clear responses to RF exposures and should investigate the effects of intermittent RF exposure. The focus should be on the expression of stress proteins and generation of reactive oxygen species (ROS) in mammalian cells.

Priority should be given to phosphorylation profiling and other high-throughput assays characteristic of genomics, proteomics, and related research areas.

\section{Laboratory studies: Dosimetry / exposure systems}

Exposure systems for in vitro and in vivo experiments should be designed as to keep physical exposure parameters under controlled conditions on the one hand, and to be able to establish electromagnetic properties of tissues and cells on the other. Exposure conditions should correspond to the use of mobile phones, which means that these studies should involve volunteering subjects. Monitoring and control of environmental factors such as external RF sources are also very important.

\section{Acknowledgement}

This research was supported by the Croatian Ministry of Science, Education and Sports (grant no. 022-0222411-2406). 


\section{REFERENCES}

1. European Commission, Scientific Committee on Emerging and Newly Identified Health Risks (SCENIHR). Health Effects of Exposure to EMF [displayed 18 January 2012] Available at http://ec.europa.eu/health/ph_risk/ committees/04 scenihr/docs/scenihr o 022.pdf

2. Independent Expert Group on Mobile Phones (IEGMP). Report of the Group (The Stewart Report) [displayed 13 July 2011]. Available at http://www.iegmp.org.uk

3. Trošić I, Pavičić I, Marjanović AM. Prednosti i mane korištenja mobilne komunikacije [Pros and Cons of Mobile Communication, in Croatian]. In: Srb N, editor. Proceedings EIS 2011 of the 22 International Conference "Electrical Engineering Symposium" Josip Lončar Days; 2-5 May 2011; Šibenik, Croatia. Zagreb: Elektrotehničko društvo Zagreb; 2011. p. 3-6.

4. Cleveland RF, Ulcek JL, Jr. Questions and answers about biological effects and potential hazards of radiofrequency electromagnetic fields. OET Bull 1999;56:1-36.

5. World Health Organization (WHO). Electromagnetic Fields (300 Hz to $300 \mathrm{GHz}$ ). Environmental Health Criteria 137. Geneva: WHO; 1993.

6. Cleary SF. In vitro studies of the effects of nonthermal radiofrequency and microwave radiation. In: Bernhard JH, Matthes R, Repacholy MH, editors. Non-thermal effects of RF electromagnetic fields. ICNIRP 3/97. München: Märk1Druck Print; 1997. p. 119-30.

7. Dasdag S, Bilgin HM, Akdag MZ, Celik H, Aksen F. Effect of long term mobile phone exposure on oxidative processes and nitric oxide in rats. Biotechnol \& Biotechnol Eq 2008;22:992-7.

8. Valko M, Leibfritz D, Moncol J, Cronin MTD, Mazur M, Tesler J. Free radicals and antioxidants in normal physiological functions and human disease. Int J Biochem Cell Biol 2007;39:44-84

9. Fröhlich $\mathrm{H}$. The biological effects of microwaves and related questions. Adv Electronics Electron Phys 1980;53:85-8.

10. Tenforde TS. Biological interactions of radiofrequency fields. In: Bernhard JH, Matthes R, Repacholy MH, editors. Nonthermal effects of RF electromagnetic fields. ICNIRP 3/97. München: Märkl-Druck Print; 1997. p. 65-78.

11. Fröhlich $\mathrm{H}$. Long-range coherence and energy storage in biological systems. Int J Quantum Chem 1968;2:641-9.

12. Adey WR. Cell and molecular biology associated with radiation fields of mobile telephones. In: Stone WR, Ueno S, editors. Review of radio science 1996-1999. Oxford: Oxford University Press; 1999. p. 845-72.

13. Trošić I, Mataušić-Pišl M, Radalj Ž, Prlić I. Animal study on electromagnetic field biological potency. Arh Hig Rada Toksikol 1999;50:5-11.

14. Kreja L, Selig C, Plappert U, Nothdurft W. Radiation-induced DNA damage in canine hemopoietic cells and stromal cells as measured by the Comet Assay. Environ Mol Mutagen 1996;45:39-45.

15. Car BD. The hematopoietic system. In: Weiss DJ, Wardrop KJ, editors. Schalm's veterinary hematology. $6^{\text {th }}$ ed. Ames; Wiley- Blackwell; 2010. p. 27-36.

16. Bušljeta I, Trošić I, Milković-Kraus S. Erythropoietic changes in rats after $2.45 \mathrm{GHz}$ nonthermal irradiation. Int J Hyg Environ Health 2004;207:1-6.
17. Bušljeta I. Utjecaj radiofrekventnog mikrovalnog zračenja na krvotvorno tkivo štakora [Impact of radiofrequency microwave irradiation on hematopoietic tissue of rats, in Croatian]. [MS thesis]. Zagreb: Faculty of Medicine, University of Zagreb; 2002.

18. Bušljeta I, Trošić I, Milković-Kraus, S. Erythropoietic aberrations in bone marrow of rats after microwave irradiation. In: Kostarakis P, editor. Proceedings of the Biological Effects of EFMs $2^{\text {nd }}$ International Workshop; 7-11 Oct 2002; Rhodes, Greece. Athens: Institute of Informatics and Telecommunications NCSR "Demokritos"; 2002. p. $739-43$.

19. Trošić I, Bušljeta I. Erythropoietic dynamic equilibrium in rats maintained after microwave exposure. Exp Toxicol Pathol 2006;57:247-51.

20. Unanue ER. Macrophages, antigen-presenting cells and phenomena of antigen handling and presentation. In: Paul WE, editor. Fundamental immunology. $3^{\text {rd }}$ ed. Philadelphia: Lipincott-Raven; 1993. p. 111-44.

21. Dasdag S, Oflazoglu H, Kelle M, Akdag Z. Efects of microwave on the phagocytic activity of variously treated rat macrophages. Electro Magnetobiol 1998;17:185-94.

22. Trošić I. Multinucleated giant cell appearance after whole body microwave irradiation of rats. Int J Hyg Environ Health 2001;204:133-8.

23. Trošić I, Bušljeta I, Pavičić I. Blood-forming system in rats after whole-body microwave exposure; reference to the lymphocytes. Toxicol Lett 2004;154:125-32.

24. Stevens RG, Davis S. The melatonin hypothesis: electric power and breast cancer. Environ Health Perspect 1996;104(Suppl 1):135-40.

25. Brainard GC, Kavet R, Kheifets LI. The relationship between electromagnetic field and light exposure to melatonin and breast cancer risk: A review of the relevant literature. J Pineal Res 1999;26:65-100.

26. Trošić I, Bušljeta I, Pavičić I, Milković-Kraus S. Nocturnal urinary melatonin levels and urine biochemistry in microwave-irradiated rats. Biologia 2009;64:798-802.

27. Pavičić I, Trošić I. Impact of $864 \mathrm{MHz}$ or $935 \mathrm{MHz}$ radiofrequency microwave radiation on the basic growth parameters of V79 cell line. Acta Biol Hung 2008;59:6776.

28. Pavičić I. Biološki pokazatelji učinka radiofrekvencijskog mikrovalnog zračenja $(935 \mathrm{MHz})$ na V79 stanice u kulturi [Biological markers of radiofrequency microwave radiation (935 MHz) effect on V79 cell culture, in Croatian] [MS thesis]. Zagreb: Faculty of Science, University of Zagreb; 2005.

29. Kwee S, Rasmark P. Changes in cell proliferation due to environmental non-ionizing radiation. 2. Microwave radiation. Bioelectrochem Bioenerg 1998;44:251-5.

30. Grundler W, Kaiser F. Experimental evidence for coherent excitations correlated with cell growth. Nanobiology 1992;1:163-76

31. Grundler W, Kaiser F, Keilmann F, Walleczek J. Mechanisms of electromagnetic interaction with cellular systems. Naturwissenschaften 1992;79:551-9.

32. Pavičić I. Djelovanje radiofrekvencijskog zračenja na strukturu citoskeleta stanica u kulturi [Influence of radiofrequency radiation on cytoskeleton structure of cells in culture, in Croatian] [PhD thesis]. Zagreb: Faculty of Science, University of Zagreb; 2008. 
33. Pavičić I, Trošić I. Influence of $864 \mathrm{MHz}$ electromagnetic field on growth kinetics of established cell line. Biologia 2006;61:321-5.

34. Ortner MJ, Galvin MJ, Irwin RD. The effect of $2450-\mathrm{MHz}$ microwave radiation during microtubular polymerization in vitro. Radiat Res 1983;93:353-63.

35. Pokorný J, Jelínek F, Trkal V, Šrobár F. Vibration in microtubules. U: Bersam F, editor. Electricity and magnetism in biology and medicine. Bologna: Kluwer Academic/Plenum Publishers; 1999. p. 967-70.

36. Pokorný J, Jelínek F, Trkal V. Electric field around microtubules. Bioelectrochem Bioenerg 1998;45:239-45.

37. Pokorný J. Excitation of vibrations in microtubules in living cells. Bioelectrochemistry 2004;63:321-6.

38. Trošić I, Pavičić I, Bušljeta I, Mataušić-Pišl M, MilkovićKraus S. Djelovanje radiofrekvencijskog pojasa neionizirajućeg elektromagnetskog zračenja na razini stanice [Activity of radiofrequency radiation at the cell level, in Croatian]. Arh Hig Rada Toksikol 2010;61(Suppl):45-52.

39. Pavičić I, Trošić I. In vitro testing of cellular response to ultra high frequency electromagnetic field radiation. Toxicol in Vitro 2008;22:1344-8.

40. Pacini S, Ruggiero M, Sardi I, Aterini S, Gulisano F, Gulisano M. Exposure to global system for mobile communication (GSM) cellular phone radiofrequency alters gene expression, proliferation, and morphology of human skin fibroblasts. Oncol Res 2002;13:19-24.

41. Stagg RB, Thomas WJ, Jones RA, Adey WR. DNA synthesis and cell proliferation in $\mathrm{C} 6$ glioma and primary glial cells exposed to a $836.55 \mathrm{MHz}$ modulated radiofrequency field. Bioelectromagnetics 1997;18:230-6.
42. Bohr H, Bohr J. Microwave-enhanced folding and denaturation of globular proteins. Phys Rev E 2000;61:4310-4.

43. Bohr H, Bohr J. Microwave enhanced kinetics observed in ORD studies of a protein. Bioelectromagnetics 2000;21/1, 68-72.

44. George DF, Bilek MM, McKenzie DR. Non-thermal effects in the microwave induced unfolding of proteins observed by chaperone binding. Bioelectromagnetics 2008;29:324-30.

45. Leszczynski D, Joenvaara S, Reivinen J, Kuokka R. Nonthermal activation of the hsp27/p38MAPK stress pathway by mobile phone radiation in human endothelial cells: Molecular mechanisms for cancer- and blood-brain barrierrelated effects. Differentiation 2002;70:120-9.

46. Marjanović AM, Domjan A-M, Fleis D, Pavičić I. Pokazatelji oksidacijskog oštećenja makromolekula i antioksidacijske obrane u ispitanika izloženih radarskom zračenju frekvencija od 1,5 GHz do 10,9 GHz [Indicators of macromolecular oxidative damage and antioxidant defence in examinees exposed to the radar frequencies 1.5-10.9 GHz, in Croatian]. In: Krajcar Bronić I, Kopjar N, Milić M, Branica G, editors. Proceedings of the Eight Symposium of the Croatian Radiation Protection Association. 13-15 April 2011; Krk, Croatia. Zagreb: Denona; 2011. p. 513-7.

47. WHO Research Agenda for Radiofrequency Fields [displayed 5 March 2012]. Available at http://whqlibdoc.who.int/ publications/2010/9789241599948_eng.pdf

48. Repacholi MH. Health risks from the use of mobile phones. Toxicol Lett 2001;120:323-31. 


\section{Sažetak}

\section{NE-TERMALNI BIOPOKAZATELJI IZLOŽENOSTI RADIOFREKVENCIJSKOM/MIKROVALNOM ZRAČENJU}

Svrha rada je prikaz više hipoteza o biološkom djelovanju ne-termalnih razina radiofrekventnog/mikrovalnog (RF/MW) zračenja i rasprava o rezultatima vlastitih istraživanja na životinjama i in vitro. Istraživanje djelovanja elektromagnetskih polja na organizam uključilo je proučavanje hematopoieze u štakora povremeno izloženih ne-termalnom radiofrekventnom/mikrovalnom (RF/MW) zračenju tijekom supkroničnog pokusa. Rezultati su pokazali neravnotežu u proliferaciji i diferencijaciji stanica koštane srži što se odrazilo na stanične parametre u krvi štakora. U primijenjenim uvjetima zračenja nađeno je da RF/MW može privremeno destabilizirati metabolizam melatonina bez štetnog utjecaja na zdravlje životinja. Razmatrana je mogućnost aktivacije prilagodbenog mehanizma na stres izazvan zračenjem jer smatramo da su nađene promjene prije znak adaptacije nego štetnog učinka zračenja. Pristup temeljnim mehanizmima biološkog djelovanja RF/MW zračenja uključio je istraživanje parametara staničnog rasta, sposobnosti stvaranja kolonija, vijabilnosti te polarnih i nepolarnih proteinskih struktura citoskeleta nakon ozračivanja stanica. Reverzibilne promjene staničnih svojstava koje su nađene upućuju na značajnu opstrukciju staničnog rasta. Za razliku od nepolarnih intermedijarnih proteina, unutarstanična polarna vlakna mikrotubula i aktina su, ovisno o vremenu izloženosti, pokazala značajna oštećenja uzrokovana zračenjem. Statistički značajno promijenjeni parametri smatrani su biomarkerima izloženosti. Istaknuta je potreba za budućim istraživanjima koja uključuju epidemiološke, laboratorijske i dozimetrijske studije.

KLJUČNE RIJEČI: biološki pokazatelji, in vitro, in vivo, ne-termalno, $R F / M W$, zračenje

\section{CORRESPONDING AUTHOR:}

Ivančica Trošić

Institute for Medical Research and Occupational Health

Ksaverska cesta 2, HR - 10000 Zagreb, Croatia

E-pošta: itrosic@imi.hr 